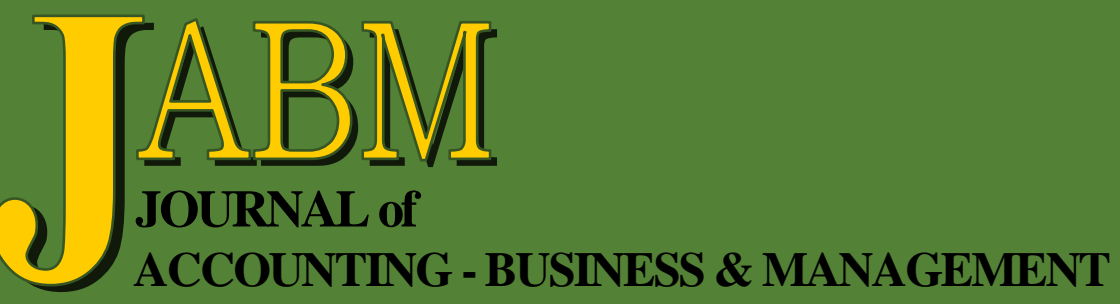

Confidence Crisis in the Application of Cloud Computing in the Industrial Companies in Jordan a Field Study

Abdullah Mohammed Al-Zoubi and Ibtissam Al-Masaiid

Comparative Analysis on Corporate Disclosure Practices of Listed Companies in ASEAN-5 after the Adoption of the Renewal Regional Disclosure Standards

Nunthapin Chantachaimongkol and Shuwen Chen

Capital Structure, Ownership Structure and Corporate Governance of SMEs in Ghana

Ibrahim Anyass Ahmed

The Tax Cuts and Jobs Act and the Middle Class

Deborah Combs and Brian Nichols

The Locus of Innovation: A Literature Review

Yongliang Stanley Han 
Journal of Accounting - Business \& Management vol. 26 no. 1 (2019) 45-56

\title{
Capital Structure, Ownership Structure and Corporate Governance of SMEs in Ghana
}

\author{
Ibrahim Anyass Ahmed*
}

\begin{abstract}
The purpose of this paper is to investigate the relationship between three variables; capital structure, ownership structure and corporate governance. Although these issues have been largely researched, less attention has been focused on small and medium enterprises (SMEs). At the time of this study, evidence was not found for a study analyzing all three variables in relation to SMEs, within the context of a developing country. This current study examines the link between capital structure, ownership structure, and corporate governance. Using an appropriate regression model, the study assesses how governance mechanisms and ownership decisions affect the choice of financing SMEs. The results show a positive relationship for all corporate governance variables except for board size. Ownership structure is found to be positive and significantly related to capital structure. The signs indicated by control variables are those which are in consonance with conventional capital structure literature. Generally, ownership and corporate governance are found to affect the financing mix of SMEs in Ghana.
\end{abstract}

Keywords: corporate governance, ownership structure, capital structure, SMEs, Ghana.

\section{INTRODUCTION}

The performance of companies has generally been attributed to good corporate governance. The need to enhance and maximize the wealth of stakeholders is what continues to ensure the relevance of corporate governance in most countries. In a nutshell, effective corporate governance continues to be critical to all economic transactions especially in emerging and transition economies (Dharwardkar et al., 2000) and it also deals with the management and supervisory system of companies, representing the legal and factual regulation framework for the interaction of management, board and stakeholders (Bassen et al., 2007).

Empirical literature does not however provide a single definition for corporate governance. According to Keasey et al. (1997), corporate governance is defined to encompass factors which engender the successful operation of organizations. These factors include: structures, processes, cultures, and systems. In the view of Deakin and Hughes (1997) corporate governance is concerned with the relationship between the internal governance mechanisms of corporations and society's conception of the scope of corporate accountability. Mayer (1997) contends that there is always a conflict between the interest of managers and investors which is resolved by bringing the interests of these parties together. The resolution of this conflict will require putting in place good corporate governance mechanisms. Evident from the above definitions is a clear indication that, corporate governance concerns itself with structures, principles, procedures, and systems that reduce potential conflicts among parties and in the long

\footnotetext{
* Department of Accounting, School of Business, University of Education, Winneba-Ghana.

E-mail: mamastughosh@gmail.com.
} 
run, maximizing the value of interested parties as a result of separation of ownership from management, which arises from the agency situation.

However, literature fails to provide conclusive evidence of the relationship between corporate governance, ownership structure and capital structure. Whiles most empirical literature has focused on the relationship between corporate governance and performance or corporate governance and firm value, it is imperative to examine the relationship between all these variables. This is because corporate governance, which is critical to the survival of most companies, continues to be a growing area of management research. It is also worthy of mentioning that, studies such as that of Abor (2007), Berger et al. (1997), Wen et al. (2002), and Friend and Lang (1988) focus on emerging markets, discussing the influence corporate governance has on capital structure. Again, Sanda et al. (2005) examined corporate governance and its influence on financial performance in Nigeria whiles Kyereboah-Coleman and Biekpe (2006) conducted a comparative study of listed and non-listed banks in Ghana, by looking at relationships between corporate governance and financial performance. Recently, Agyei and Owusu (2014) focused on corporate governance, ownership and capital structure in relation to listed manufacturing firms in Ghana. Although the current study combines all three variables it focuses on non-listed manufacturing firms.

In Africa just like other continents, corporate governance issues are widely driven by country-specific principles and laws (Kyereboah-Coleman, 2008). These include Company Codes, Rules of the Securities and Exchange Commissions, the stock exchange listing requirements, and regulations from supervisory agencies. Although most companies in developing nations are embracing the notion of corporate governance, insufficient empirical research does not allow for a comparison with the experiences of other continents (Bansal, 2005).

This study therefore, adds to the existing literature on corporate governance as well as examining its relationship with capital structure and ownership structure. Within the Ghanaian context, the study focuses on SMEs-non-listed firms, unlike that of Agyei and Owusu (2014) which focused on listed manufacturing firms. The rest of the study is structured as follows; section two reviews the literature on the subject matter; section three discusses the variables, data and the methodology of the study; section four discusses and presents the findings of the study; and section five finally provides a brief conclusion and highlights policy implications.

\section{LITERATURE REVIEW}

\subsection{Ownership Structure and Capital Structure}

Jensen and Meckling (1976) provide an understanding of ownership structure based on a classification of interests. Here, ownership structure comprises inside investors (managers) and outside investors (providers of debt and equity finances). This classification reduces the desire for managers to consume perquisites (Jensen \& Meckling, 1976) whiles maximizing the wealth or interest of shareholders. Viewed differently, ownership structure, according to Ezeoha and Okafor (2010) is the percentage of ownership in a business including those of central government, foreign investors, families, institutions, and managers.

Berger et al. (1997) examined the relationship between managerial entrenchment and the capital structure of a firm. Findings show that, gearing ratio will remain low when owners do not make demands on the firm whereas managers whose positions are entrenched shy away from gearing and taking debt. Also, when steps such as threats to replace CEOs and board members are adopted, gearing levels increases. In a related 
study, Butt and Hasan (2009) conclude that in Pakistan, managerial ownership significantly affects capital structure represented by debt to equity ratio. Agyei and Owusu (2014) revealed a positive relationship between capital structure and institutional and managerial ownership.

The results of Hasan et al. (2009) indicate managerial ownership significantly affecting capital structure represented by debt to equity ratio. The study by Bodaghi and Ahmadpour (2010) indicates that institutional ownership has positive relationship with capital structure consistent with corporate governance philosophy.

\subsection{Board Size and Capital Structure}

The size of a company relatively indicates its board's composition. This could affect the capital structure of the company and arguably, the level of financing. In the view of Jensen (1986), companies with high gearing level rather have larger boards.

Wen et al. (2002) point to a positive relationship between capital structure and board size. The study portends that, in order to maximize firm value, large boards will normally adopt a policy that will lead to high gearing level. Abor and Biekpe (2007) provide evidence of a negative relationship between board size and leverage ratios of small and medium-sized Ghanaian enterprises. They conclude that SMEs with large boards will conventionally have low gearing levels. Using regression analysis, Bodaghi and Ahmadpour (2010) revealed that board size relates significantly with capital structure. However, results in relation to evidence of directional relationship for the two variables were mixed.

\subsection{Non-Executive Directors and Capital Structure}

Modern corporate governance argues for the inclusion of non-executive directors in the composition of boards. According to Hasan et al. (2009), non-executive directors are the cornerstone of modern corporate governance. Yet, empirical literature in relation to capital structure and non-executive directors provides mixed results.

For instance, Abor and Biekpe (2007) provide evidence on the presence of positive relationship between gearing levels and CEO duality, board skills and board composition. Arguing further, they conclude that SMEs with higher gearing have relatively more outside directors with specialized and diversified skills. Board size and capital structure have positive and significant association and such relationships lead to better financial decision (Bokpin \& Arko, 2009). Lipton and Lorsch (1992) found that when non-executive directors are highly represented on boards, gearing levels are high. This is premised on the notion that non-executive directors play a cardinal role in drawing external stakeholders close to the company.

\subsection{CEO Duality and Capital Structure}

Duality depicts the role of a single individual as a board chairman and CEO of a company. When this happens, it is likely to lead to agency problems and affect the financial decisions of the firm (Kyereboah-Coleman \& Biekpe, 2006). Just as board size, the relationship between this variable and capital structure has been diverse. When a CEO does not assume the position of chairman, the firm is likely to get a greater share in the financial market (high leverage) and also have superior financial results (Brown \& Caylor, 2009). However, Bokpin and Arko (2009) argue that CEO duality compels a firm to dwell on equity rather than leverage, while reporting a negative association between CEO duality and leverage. Fosberg (2004) finds that firms with a separate chairman and CEO employ the optimal amount of debt in their capital structures. 


\section{RESEARCH METHODOLOGY}

The study employs the explorative research approach to examine the relationship and effect corporate governance and ownership structure have on capital structure. Sampled companies were selected from the database of the Association of Ghanaian Industries, the National Board for Small Scale Industries, and the Ghana Club 100. Sampled companies selected for the study are those with employees size less than 100, in line with Abor and Biekpe (2007), following the criteria set by the Regional Project on Enterprise Development (RPED) for SMEs in Ghana. Data was derived from the financial statements of 50 firms during a six year period, 2010 - 2016; resulting in total of 202 firm year observations instead of 300. Information on corporate governance variables was obtained through survey and interviews albeit cumbersome in most instances. The regression model was adopted from Hasan et al. (2009). The model takes the form:

\section{LEVit $=\beta_{0}+\beta_{1}(\operatorname{LogBZ})$ it $+\beta_{2}(\%$ NED $)$ it $+\beta_{3}(\%$ INSTSH $)$ it $+\beta_{4}(\%$ MANGSH $)$ it $+\beta_{5}($ ROA $) \mathrm{it}+\beta_{6}(\operatorname{LogSZ}) \mathrm{it}+\beta_{7}($ DUALITY $) \mathrm{it}+\varepsilon \mathrm{t}$}

Where:

LEV = leverage (total debt to equity),

$\mathrm{BZ}=$ board size (logarithm of total number of board members),

$\mathrm{NED}=$ non-executive directors (number of non-executive directors divided by total number of directors),

INSTSH= institutional shareholding (percentage as given shown in the annual report \&Survey), MANGSH= managerial shareholding (percentage as given shown in the annual report\& survey), $\mathrm{ROA}=$ return on assets (company's EBIT divided by its total assets),

$\mathrm{SZ}=$ size of firm (as logarithm of total assets),

DUALITY $=\mathrm{CEO} /$ chair duality (dummy variable, It is taken as 1 if CEO is chairman; otherwise it is taken as 0 ),

$\varepsilon \quad=$ error term,

$\beta_{0}=$ intercept of the equation, and

$\beta=$ marginal effect of variable on debt to equity ratio.

The variables used to operationalize the constructs included the dependent, independent and control variable. The dependent variable, capital structure was operationalized using leverage. Independent variables included corporate governance (board size, CEO duality, and board composition) and ownership structure (institutional and managerial ownership). Control variables were firm size and return on assets.

\section{ANALYSIS AND DISCUSSION OF EMPIRICAL RESULTS}

\section{Table 1}

Descriptive Statistics of Variables

\begin{tabular}{lccccc}
\hline \multicolumn{1}{c}{ Variable } & Mean & Median & Std. Dev. & Min. & Max. \\
\hline Leverage & 0.52 & 0.48 & 0.50 & 0.07 & 4.62 \\
Board Size & 3.65 & 4.10 & 0.95 & 1.00 & 9.00 \\
Board Composition & 0.46 & 0.34 & 0.27 & 0.00 & 1.00 \\
CEO Duality & 0.65 & 1.00 & 0.43 & 0.00 & 1.00 \\
INSTSH & 0.09 & 0.06 & 0.06 & 0.04 & 0.11 \\
MANGSH & 0.81 & 0.89 & 17.23 & 0.47 & 0.91 \\
Firm Size & 19.09 & 18.90 & 1.34 & 14.36 & 22.14 \\
ROA & 0.10 & 0.07 & 0.25 & -0.96 & 3.14 \\
\hline
\end{tabular}

Table 1 provides a summary of the descriptive statistics of the dependent, independent and control variables. It depicts the average of each indicator employed 
for the study. The mean (median) leverage of the firms is $0.52(0.48)$ respectively. This means that leverage appears to constitute slightly more than half of the capital mix of SMEs. By implication, $52 \%$ of total assets are financed by debt capital. The average board size of SMEs is 3.65 (for mean) and (4.10) for median. The proportion of outside directors represented by NED is $46 \%$. This appears to be a fairly good representation. Most CEOs play dual roles in companies represented by a mean of $65 \%$. In most firms therefore, owners who double as managers operate as chairperson of the boards constituted. Average ROA, registers a mean value of $10 \%$. The size of SMEs, given as the natural logarithm of total assets has a mean (median) of 19.09 (18.90). Managerial ownership is approximately $81 \%$ whereas institutional ownership is relatively low at $9 \%$. This only reinforces the nature of non-listed companies, which are mostly individually owned in Ghana.

\section{Table 2}

\section{Regression Model Results}

\begin{tabular}{lcccc}
\hline \multicolumn{1}{c}{ Variable } & Coef. & Std. Error & T-statistic & Prob. \\
\hline Constant & -0.913 & 0.045 & -15.61 & 0.0000 \\
Board Size & -0.032 & 0.003 & -5.24 & 0.0000 \\
Board Composition & 0.075 & 0.019 & 3.68 & 0.0113 \\
Duality & 0.148 & 0.082 & 15.04 & 0.0115 \\
INSTSH & 0.007 & 0.121 & 5.992 & 0.0127 \\
MANGSH & 0.013 & 0.022 & 0.592 & 0.0000 \\
Firm Size & 0.047 & 0.001 & 19.89 & 0.0623 \\
ROA & -0.354 & 0.048 & -9.27 & 0.0000 \\
R-Squared & & 0.768 & & \\
Std. Error of Regression & & 0.324 & & \\
F-statistic & & 756.64 & & \\
Prob. (F-statistic) & & 0.0000 & & \\
\hline
\end{tabular}

The relationship between the dependent variable and the two independent variables is investigated using regression analysis. After testing for Fixed and Random Effects of the panel data, the Ordinary Least Square (OLS) panel was found to be the most robust for this study and is presented in Table 2. The F-statistic corroborates the validity of the estimated model. This is because the results from the regression model denote that $76.8 \%$ of the independent variables explain the dependent variable; leverage.

Board size was found to be related, significantly to capital structure. This suggests that large boards employ low debt policy. As with previous studies, Abor and Biekpe (2007) argue that SMEs with larger boards try to impress on owner-managers to employ more equity capital. There is thus a coercion to employ external equity to help improve performance. This finding is consistent with those of Berger et al. (1997), Abor and Biekpe (2007) and Bodaghi and Ahmadpour (2010).

In Ghana, the appointment of board members, an executive and non-executive director(s) is the sole responsibility of the firm (Abor, 2007). The companies' code of Ghana does not enforce the composition of membership of boards. The results of this study indicate a positive sign for board composition, i.e. the percentage of nonexecutive directors on the board. The significant positive relationship between this variable and leverage suggests that SMEs with more non-executives on boards are more likely to have easy access to loans (Jensen, 1986). These results however contradict the findings of Hasan et al. (2009). 
CEO duality is shown to have a significant positive relationship with leverage. In a related study, Fosberg (2004) finds that firms with separate chairman and CEO employ the optimal amount of debt in their capital structures. Firms with CEO as board chairman tend to employ higher proportion of debt in their capital mix. Supporting this is the mean value of CEO duality shown in Table 1.

The results of this study show a positive significant relationship between managerial ownership and capital structure as in Duxbury et al. (2002). Friend and Lang (1988) portend that in the absence of significant shareholding; the motivation to have lower debt to equity will continue and will result in macro-economic risk. Equally, institutional ownership is found to be significantly and positively related to capital structure. This contradicts the findings of Hasan et al. (2009) who report an insignificant impact of institutional ownership on capital structure.

The control variables in the model show signs which are consistent with capital structure theories. The negative relationship between ROA-profitability and leverage is expected. As espoused by Abor and Biekpe (2007), SMEs with high profit margins increase the level of internal financing. This indicates that profitable firms may have better access to debt finance than less profitable firms.

\section{CONCLUSIONS AND RECOMMENDATIONS}

This study examines the relationship between ownership structure, capital structure, and corporate governance using multivariate regression model. The study focused on SMEs for the period 2010-2016. Results indicate that, board size significantly influences capital structure, thus implying that large boards are likely to opt for low debt policy. NED is found to be positive and significant, hence providing an opportunity for easy access to loans.

The study also shows the ability of CEOs with multiple roles in a firm to use an optimal level of debt in their capital mix. Ownership structure is found to be significantly related to capital structure. By this, managerial ownership reduces gearing levels. Conventional variables such as profitability and size were also significantly related to financing decisions of firms. The negative co-efficient of profitability is in line with the pecking order theory. The positive relationship between firm size and financing indicates the ability of large firms to access loans based on longstanding relations and ability to offer collateral.

Both corporate governance and ownership can greatly assist the SME sector when appropriate management practices, proper accounting controls, and resources are utilized to the maximum. As shown in the study, SMEs with well-established corporate governance structures have superior advantages in accessing credit facilities. It is therefore imperative for firms in Ghana to take advantage of corporate governance mechanisms in the wake of happenings within the financial sector of Ghana.

\section{REFERENCES}

Abor, J. (2007). Corporate governance and financing decisions of Ghanaian listed firms. Corporate Governance: International Journal of Business in Society, 7(1), 83-92.

Abor, J., \& Biekpe, N. (2007). Corporate governance, ownership structure and performance of SMEs in Ghana: Implications for financing opportunities. Corporate Governance: The International Journal of Business in Society, 7(3), 288-300.

Agyei, A., \& Owusu, A. R. (2014). The effect of ownership structure and corporate governance on capital structure of Ghanaian listed manufacturing companies. 
International Journal of Academic Research in Accounting, Finance and Management Sciences, 4(1), 109-118.

Bansal, C. L. (2005). Corporate governance: Law practice and procedures with case studies (pp. 163-234). New Delhi: Taxmann Allied Service (P) Ltd.

Bassen, A., Schiereck, D., \& Zöllner, C. (2007). Anti-Takeover-Maßnabmen aus CorporateGovernance-Sicht (No. 34974). Darmstadt Technical University, Department of Business Administration, Economics and Law, Institute for Business Studies (BWL).

Berger, P. G., Ofek, E., \& Yermack, D. L. (1997). Managerial entrenchment and capital structure decisions. Journal of Finance, 52(4), 1411-1438.

Bodaghi, A., \& Ahmadpour, A. (2010, June 28-29). The effect of corporate governance and ownership structure on capital structure of Iranian listed companies (pp. 28-29). In $7^{\text {th }}$ International Conference on Enterprise Systems, Accounting \& Logistics $7^{\text {th }}$ ICESAL 2010). Rhodes Island, Greece.

Bokpin, G. A., \& Arko, A. C. (2009). Ownership structure, corporate governance and capital structure decisions of firms: Empirical evidence from Ghana. Studies in Economics \& Finance, 26(4), 246-256.

Brown, L. D., \& Caylor, M. L. (2009). Corporate governance and firm operating performance. Review of Quantitative Finance \& Accounting, 32(2), 129-144.

Butt, S. A., \& Hasan, A. (2009, February). Impact of ownership structure and corporate governance on capital structure of Pakistani listed companies. International Journal of Business \& Management, 4(2), 50-57.

Deakin, S., \& Hughes, A. (1997). Comparative corporate governance: An interdisciplinary agenda. Journal of Law \& Society, 24(1), 1-9.

Dharwardkar, B., George, G., \& Brandes, P. (2000). Privatization in emerging economies: An agency theory perspective. Academy of Management Review, 25(3), 650-669.

Duxbury, D., Short, H., \& Keasey, K. (2002). Capital structure, management ownership, and large external shareholders: A UK analysis. International Journal of the Economics of Business, 9(3), 375-399.

Ezeoha, A. A., \& Okafor, F. O. (2010). Local corporate ownership and capital structure decisions in Nigeria: A developing country perspective. Corporate Governance: The international Journal of Business in Society, 10(3), 249-260.

Fosberg, R. H. (2004). Agency problems and debt financing: Leadership structure effects. Corporate Governance: The International Journal of Business in Society, 4(1), 3138.

Friend, I., \& Lang, L. H. P. (1988). An empirical test of the impact of managerial self-interest on corporate capital structure. Journal of Finance, 43(2), 271-81.

Hasan, A., Jinnah, M. A., \& Butt, S. A. (2009). Impact of Ownership Structure and Corporate Governance on Capital Structure of Pakistani Listed Companies. International Journal of Business \& Management, 2(4), 50-57.

Jensen, M. C. (1986). Agency costs of free cash flow, corporate finance, and takeovers. The American Economic Review, 76(2), 323-329.

Jensen, M. C., \& Meckling, W. H. (1976). Theory of the firm: Managerial behavior, agency costs and ownership structures. Journal of Financial Economics, 3, 305-360.

Keasey, K., Thompson, S., \& Wright, M. (1997). Corporate governance: Economic and financial issues. Oxford University Press.

Kyereboah-Coleman, A. (2008). Corporate governance and firm performance in Africa: A dynamic panel data analysis. Studies in Economics \& Econometrics, 32(2), 1-24. 
Kyereboah-Coleman, A., \& Biekpe, N. (2006). The relationship between board size, board composition, CEO duality and firm performance: Experience from Ghana. Corporate Ownership \& Control, 4(2), 114-122.

Lipton, M., \& Lorsch, J. W. (1992). A modest proposal for improved corporate governance. The Business Lawyer, 48(1), 59-77.

Mayer, C. (1997). Corporate governance, competition, and performance. Journal of Law \& Society, 24(1), 152-176.

Sanda, A. U., Mikailu, A. S., \& Garba, T. (2005 March). Corporate governance mechanisms and firm financial performance in Nigeria (pp.1-41). AERC Research Paper 149. The African Economic Research Consortium: Nairobi, Kenya.

Wen, Y., Rwegasira, K., \& Bilderbeek, J. (2002). Corporate governance and capital structure decisions of Chinese listed firms. Corporate Governance: An International Review, 10(2), 75-83. 